\title{
Structural Capital Management: A Guide For Indicators
}

\author{
$M^{a}$ Teresa García-Álvarez, University of La Coruña, Spain \\ Rosa M Mariz-Pérez, University of La Coruña, Spain \\ Mercedes Teijero Álvarez, University of La Coruña, Spain
}

\begin{abstract}
Intellectual Capital is of vital importance, both for the scientific community and business reality. For this reason, over the past decades its relevance has rapidly increased. Within Intellectual Capital (from here on IC), Structural Capital (from here on, SC) plays an outstanding paper, given that is represents the part of knowledge that the organization is able to explicit, systematize and internalize and that, initially, is latent in employees or teams. This type of capital allows for organizational effectiveness improvement through the transmission of knowledge.
\end{abstract}

The objectives of this paper is, first, to identify the elements of IC that help to guarantee the success of companies belonging to a given sector, paying special attention to the contributions of SC to IC. Second, and after observing that most existing papers are centered only on the measurement of SC and, therefore, leave aside elements regarding its management, our proposal fills this gap and includes various general indicators for SC that may help to manage it adequately. The basic aim is to allow managers themselves to choose the most adequate indicators within those presented, taking into account, of course, characteristics, objectives and strategies of the companies they manage

Keywords: intellectual capital; structural capital management; indicators

\section{INTRODUCTION}

O ntil the nineteen eighties management theory was focused on the analysis of firm environment in order to understand competitive advantages (Ross y Ross, 1997). In this sense, Porter (1980) establishes that there are five structural variables that determine competitive advantages and, therefore, performance: industry rivalry, the threat of new competitors, the treat of substitute products and negotiation power of suppliers and clients. In line with this framework, firm profitability will be determined by a series of external factors to industry. However, resources of firms belonging to the same industry are also characterized by being distributed in a heterogenic manner and by not being easily imitable. Therefore, these resources are a potential source of competitive advantages.

It is in this context where the Resource-based view appears (Barney, 1986; Wernerfelt, 1984). This framework establishes that firms internal resources -more than industry resources- are a key element to obtain sustainable competitive advantages.

With regard to this and to the basic purpose of this paper, it is important to keep in mind that one of the consequences of globalization is that world changes take place and, therefore, that knowledge becomes a crucial firm resource. Today, we must take into account that a relevant portion of firm knowledge is engaged in intangible assets. In order to create and maintain competitive advantages, firms must have workers with adequate professional competencies, attitudes and intellectual agility, permanent innovation processes, client fidelity. Good relations within workforce, adequate organizational technology, the capacity to bring in and retain the best professionals, etc. All these intangible assets are commonly named Intellectual Capital -from here on, IC- and most papers establish that it is composed of three elements: Human Capital -from here on, HC-, Structural Capital and Relational Capital (Edvinson y Malone, 1997; Bontis et al., 2000; European Commission, 2006). 
In this paper we identify the elements of IC that can contribute to guaranteeing success of firms in a given industry. We pay special attention to the contribution of SC to IC. Second, and taking into account previous research, we identify a series of general indicators for SC to help organizations measure and mange this item.

This paper is structured as follows. In the next section we revise the concepts of IC and SC and analyze the evolution of the latter. Section three presents the literature review and, therefore, we describe existing models and their contribution to SC. Section four includes our proposal for SC measurement and, lastly, conclusions are presented.

\section{EVOLUTION OF INTELLECTUAL CAPITAL. STRUCTURAL CAPITAL}

We can consider that the origin of IC is placed in the early nineteen nineties when a group of firms (Skandia, Dow Chemicals y el Canadian Imperial Bank) employ the term to make reference to all intangible assets. Work of Stewart (1996) and Edvinsson and Malone (1999) is outstanding in this field.

Therefore, we can say that formally, IC is a rather new discipline and that its conceptualization is quite heterogeneous, although some definitions present only minor differences. Table 1 shows a general revision of these concepts with the objective of reaching a more homogeneous definition of IC and of the dimensions it includes. Before moving on, it is worth stating that the terms "intangible resources or assets" and IC are often employed as synonymous (Lev, 2001), although the first of these is strongly related to accounting while the latter is closer to organizational theory.

Table 1: Concept Of IC

\begin{tabular}{|l|l|}
\hline \multicolumn{1}{|c|}{ Authors } & \multicolumn{1}{c|}{ Definition of IC } \\
\hline Edvinsson and Malone (1997) & $\begin{array}{l}\text { Knowledge, applied experience, organizational technology, relations with customers and } \\
\text { professional skills that give organizations competitive advantages in the market. }\end{array}$ \\
\hline Sveibi (1997) & $\begin{array}{l}\text { Combination of intangible assets that generate organizational growth, renovation, efficiency } \\
\text { and stability. }\end{array}$ \\
\hline Bontis (1998) & Intangible resources of the firm \\
\hline Lev (2001) & $\begin{array}{l}\text { Basic relations between innovation, organizational practices and human resources that generate } \\
\text { intangible assets. }\end{array}$ \\
\hline Bradley (1997) & $\begin{array}{l}\text { Skills related to the transformation of knowledge and intangible resources into resources that } \\
\text { create wealth, both for organizations and nations. }\end{array}$ \\
\hline Bueno (2005) & $\begin{array}{l}\text { Accumulation of knowledge that creates value or cognitive wealth of an organization and that is } \\
\text { compound of different intangible assets (intellectual) or resources and capacities based on } \\
\text { knowledge. When these are activated in conjunction with other tangible or physical assets, the } \\
\text { firm produces goods and services and generated competitive advantages or essential } \\
\text { competencies in the market. }\end{array}$ \\
\hline
\end{tabular}

Based on the above revision, we can say that many definitions of IC exist but that all of them have in common certain essential characteristics, such as the notion of intangibility and the capacity these assets have in order to generate value for the organization.

It is important to keep the above elements in mind given that IC does not include all the intangible resources and capacities a given organization possess, but only those that have the potential to create competitive advantages and, therefore, value (Martín de Castro, G. , García Muiña, F.E. , 2003). 
As we earlier stated, there is an important grade of consensus within the literature with respect to the components of IC; these are, Human Capital, Structural Capital and Relational Capital. People -HC- create knowledge that is used, shared and disseminated throughout the organization - RC- and, finally, it is institutionalized and codified by firms -SC- (Martin \& García, 2003).

In this context, Nonaka (1991) establishes that both HC and RC are the base of all organizational knowledge creation. However, if firms should want to protect this asset from the threat of loosing valuable and key employees or outside relations, they should institutionalize it through routines, culture, structure, etc. and, therefore, employ it all over the organization.

In order to further delimit this concept, table 2 presents a schematic revision of the different existing definitions and concepts for SC.

Table 2: Conceptualización del Capital Estructural

\begin{tabular}{|l|l|}
\hline \multicolumn{1}{|c|}{ Authors } & \multicolumn{1}{c|}{ Definitions of Structural Capital } \\
\hline Alama (2007) & Intangibles that determine the manner of working of a company. \\
\hline Carson et al. (2004) & Processes and procedures that arise from employee intellectual contribution. \\
\hline Ordoñez de Pablos (2004) & $\begin{array}{l}\text { Knowledge that remains in the organization when employees return to their homes and, } \\
\text { therefore, is owned by the firm. In this sense, SC is integrated by organizational routines, } \\
\text { strategies, process manuals and databases. }\end{array}$ \\
\hline Zornosa et al. (2000) & $\begin{array}{l}\text { Knowledge that the organization has internalized and that remains within its structure } \\
\text { processes or culture although employees leave. }\end{array}$ \\
\hline Kogut y Zander (1996) & $\begin{array}{l}\text { Elements that belong to the organization and that facilitates its configuration as an entity } \\
\text { providing coherence and superior principles for coordination. }\end{array}$ \\
\hline Euroforum (1998) & Knowledge that can be reproduced and shared and, therefore, becomes somewhat explicit. \\
\hline Bontis (1996) & $\begin{array}{l}\text { Those technologies, methodologies and processes that make the functioning of the organization } \\
\text { possible, this is, basically the elements that define the working mode of the firm. }\end{array}$ \\
\hline
\end{tabular}

Unlike the relative existing consensus regarding the terms of $\mathrm{HC}$ and $\mathrm{RC}, \mathrm{SC}$ is subject to the use of different conceptual approaches. Some papers analyze SC as an aggregate concept and include all different forms of knowledge created, integrated, disseminated and used in the organizations (Sveiby, 1997). However, this focus does not allow for the identification of homogenous blocks of knowledge which would contribute to improve organizational management. It is for this reason that it is important to separate two basic components of SC Organizational Capital and Technological Capital- and anazlyze them separately (Edvinsson, 1997).

Technological Capital is analyzed from both a Resource-based and an Innovation and Technology Management perspectives (Collis y Montgomery, 1995). This variable includes the set of capacities necessary for employees to perform the basic functional activities in the present moment or those that would be necessary to undergo an innovation process with the consequent need to renovate functional competencies in accordance to market requirements (Martin y García, 2003).

The second component, Organizational Capital, is integrated by systematic or internalized organizational knowledge, such as organizational routines, decision-making processes or planning and control systems. In this sense, it includes an improvement in the transfer of knowledge and, therefore, an efficacy improvement because firm functions are more adequately integrated.

\section{COMPONENTS AND DIMENSIONS OF SC WITHIN IC MODELS}

In this section we outline the basic elements of the existing models of IC with respect to their contribution to SC (Cabo, 2006). 


\section{Integral Credit Scorecard Model (Kaplan And Norton, 1.992)}

It can be considered one of the first attempts to overcome limitations associated to the financial perspective and it includes a global and systemic vision of organizational strategy.

This model highlights that Organizational Capital provides the capacity to integrate intangible assets associated to $\mathrm{HC}$, informational assets and financial or tangible investments. In this manner, they are not only aligned with business strategy but, at the same time, they are integrated and jointly functioning and this will, ultimately, favor reaching organizational strategic goals. Organizational Capital includes the following elements:

1. Culture: to be conscious and to have internalized the mission, vision and the basic values that are key for strategy implementation.

2. Leadership: availability of qualified leaders for all levels in order to carry out strategy.

3. Alignment: individual team and departmental objectives and incentives must be linked to strategic objectives.

4. Team-working: potential strategic knowledge that is shared throughout the organization.

\section{The Skandia Navegator Model (Edvinsson, L., 1997)}

Skandia was one of the first organizations to develop and apply tools for IC measurement. The Skandia model constitutes a strategic and operational management system based on the fact that the performance of a company comes from its capacity to create sustainable value, given the strategic vision and mission of the firm.

Within this model, SC can be broken down into two basic dimensions: Client ${ }^{1}$ and Organizational Capital.

Organizational Capital includes Process Capital and Renovation and Development Capital ${ }^{2}$. The first of these is related to the present of the organization and with the role played by technology as a useful tool to maintain the organization, improve its efficiency, productivity and to generate value. It includes all resources and activities that belong to the organization and that employees use to generate value, such as internal processes, organizational forms, informational flows or culture.

Renovation and Development Capital makes reference to those aspects that can contribute to value generation in the future through personnel development or new products and markets.

\section{Technology Broker Model (Brooking, A. 1.996)}

In this model, market value is captured as the sum of book value and IC. The latter is determined by four different categories of intangible assets: market assets, human assets, intellectual property and infrastructure assets.

Intellectual property arises from the legal protection that organizations have over those assets that have a special value for the organization given that they are exploited in an exclusive manner. Indicators of these assets include, for example, patents, know-how, production or commercial secrets, copyrights, design rights, etc.

Infrastructure assets make reference to the assets that provide order, security, correction and quality to the organization and to the context in which they are unfold and communicated to employees. Corporative culture, processes that make the functioning of the firm possible, existing company technologies, financial structure, the ease to cooperate with other organizations, information data bases regarding the market or customers and other communication systems are included.

\footnotetext{
${ }^{1}$ Client Capital is considered as an individual block in other models (Brooking, Intellect, Intangible Assets Monitor or Nova Model) and, therefore, it is not included in SC.

${ }^{2}$ The Nova Model considers Renovation and Development Capital as a dimension on its own and, therefore, it is not included within SC.
} 


\section{University of Western Ontario Model (Bontis, N., 1.996)}

Bontis considers that IC is the sum of HC, SC and RC. With regard to SC, the author considers that all intangible non-human assets are to be included. Therefore, SC is integrated by culture, internal processes and informational systems or data bases, this is, the part of knowledge that he organization has internalized and that remains within the firm -in its structure, processes or culture- although employees leave.

\section{Intangible Assets Monitor (Sveibi, K.E. 1.997)}

This model classifies intangible assets in three categories: internal structure, external structure and the competencies of employees. Therefore, the author establishes three types of indicators for each block of intangible assets. First, indicators of growth and renovation (they take into account the potential future of the company), second, efficiency indicators (they inform us about productivity of intangibles) and, third, stability indicators (they show the degree of permanence of these assets in the firm).

The internal structure includes assets related to the structures knowledge of the organization, working methods and procedures, software, dada bases, R\&D, management and administration systems, organizational culture and atmosphere. All of these belong to the firm and, therefore, remain some although employees can abandon. They can be created within the organizations or acquired from outside.

For the specific case of the internal structure of the firm, the following indicators are proposed:

- Growth and renovation indicators: investments in new methods and systems, informational systems and contribution of customers to the internal structure.

- $\quad$ Efficiency indicators: proportion of support personnel, sales per support staff, values and attitudes.

- Stability indicators: organizational age, support staff rotation.

$\bullet$

\section{Intellect Model (Euroforum, 1998)}

IC is considered to be integrated by three basic blocks: HC, SC and Relational Capital. Each one of these must be measured and managed over time and towards the future.

SC is defined as systematized knowledge that has been made explicit or has been internalized by the organization and that, initially, can be latent in people and teams. Information and communication systems, patents, available technology, working processes, management systems, etc. are included. This capital is owned by the organization.

Intangible assets included in SC are divided into the present and future dimension.

- Within the present dimension we can find, for example, organizational culture, business philosophy, strategic reflection processes, organizational structure, intellectual property, processes and product technologies, supporting and knowledge capturing processes, transmission and communication mechanisms and informational technologies.

- $\quad$ The future dimension includes the innovation processes.

\section{Organizational Learning Model Of KPGM Consulting (Aguire And Tejedor, 1998)}

This model was developed as a part of the "Logos Project: Research relating to the learning capacity of Spanish firms" by KPMG Peat Marwick Management Consulting.

According to this model, an organization can only learn if its employees do so. However, even if this happens, the knowledge produced may not be a useful asset for the organization. In order to achieve organizational learning, it is necessary to develop specific mechanisms to create, capture, store, transmit and interpret knowledge. This will contribute to make the most of and adequately use individual and team learning. 
This view considers that certain conditions must be met in order to develop attitudes, skills and learning systems. These conditions are directly related to the culture, leadership style, strategy, structure, personnel management and information and communications systems.

\section{Stewart, T.A. Model (1.997)}

IC is seen as an intangible material that can be a source of wealth. It is the sum of HC, Relational Capital and Customer Capital.

SC is considered as a collection of systems that convert individual skills into collective property. In this sense, $\mathrm{HC}$ can be employed to create value independently of employee permanance.

The author establishes a series of principles that should guide IC administration. Those related to SC are the following:

- $\quad \mathrm{SC}$ in an intangible asset that belongs to the company and, therefore, it is easily controlled by HC and Client Capital managers.

- The basic function of SC is to create a pool of knowledge to support work that is valued by customers and accelerate the information flow in the organization.

- There should be a tendency towards the substitution of expensive physical and financial assets into information and knowledge.

- $\quad$ Each company must analyze the complete value chain in order to be able to detect the part of information with higher strategic and relevant value.

Stewart (1997) presents open-natured indicators that serve as a guide and allow for each organization to include their specific needs.

\section{The Meritum Project (2000)}

Meritum (Measuring Intangibles to Understand and Improve Innovation Management) is a research project in which several countries participate -Denmark, Finland, France, Norway, Sweden and Spain-. The basic objective is to elaborate a series of guidelines to help with the measurement and diffusion of intangibles and, therefore, with the associated decision processes.

It establishes a series of indicators for intangible resources and activities that can be classifies into four basic blocks: human resources, customers, technology and organizational processes. Indicators for SC are the following:

- Technology indicators, which include total investment and operational costs in information technologies, number of computers per employee, informational technology expenses per employee and capacities of this technology.

- $\quad$ Process indicators, which make reference to the cost of the process, the distribution of employees, investments in offices and production plants, quality, processes timing and error rates.

Intellectus Model (Bueno, E. CIC, 2.003)

Intellectus is presented as an evolutionary model, based on Social Capital. The later is the sum of present and potential resources that arise from individual or social relations. social).

IC is subdivided into HC, SC (both organizational and technological) and Relational Capital (business and

SC is integrated by the set of intangible assets and knowledge that derive from the action processes and that remain within the organization although employees abandon. This type of knowledge is based on the existence of 
shared cultural values, such as data bases, procedures, protocols, routines or organizational guidelines, technological efforts and developments that constitute collective knowledge and know-how.

Specifically, SC integrated by Organizational Capital and Technological Capital:

- Organizational Capital is a set of both explicit and implicit intangibles, that can have a formal or informal nature and that contributes to effectively and efficiently structure and develop organizational activity. Basic elements of Organizational Capital include organizational culture, structure, learning paths and processes.

- Technological Capital is integrated by those intangibles that are directly linked to the development of activities and functions related to the technical system. The latter is responsible for the production of goods with certain specific attributes, the development of efficient production processes and for knowledge-based advances that are necessary to achieve future product and process innovations. Basic elements of Organizational Capital depend on R\&D effort, technological base, intellectual and industrial property and innovation results.

Once we have revised the most relevant IC models and their contribution to SC, we can establish the following conclusion:

It is rather difficult to make comparisons given the high heterogenic nature of approaches to SC. Most models are characterized by focusing on measurement, while SC management is pushed into the background.

\section{A SYSTEM OF INDICATORS FOR SC MANAGEMNT: A PROPOSAL}

To start with our SC measurement and management proposal, we will define SC "as the part of knowledge that the organization can internalize and that remains within the firm through its structure, processes or culture". Although this definition is quite short, we consider it resumes the basic contents of the concept.

In order to effective and efficiently manage any asset, it is necessary, of course, to have both adequate information and a measurement method to control and track efforts made.

Lev (2001) establishes that an effective information system is that that provides indicators capable to advance future situations, allowing managers to identify which factors are generating value. It is important for indicators to provide a clear vision of the links between organizational intangible resources and value creation. We can summary the characteristics of an adequate system of indicators as:

- $\quad$ Useful: they should make management and control decisions possible.

- $\quad$ Significant: information provided must be related to critical intangibles.

- $\quad$ Comprehensive: they must be possible to calculate and clear.

- Comparable: elaboration and presentation should be made on homogeneous criterion.

- $\quad$ To have and objective: their value should not be affected by particular interests of parties involved.

- $\quad$ True: they should reflect the true situation of the company.

- Verifiable: it must be possible to check the veracity of the information provided.

Nevertheless, the fundamental aim of a system of indicators for SC is not to value o measure knowledge directly, but to improve the capacity to create and exploit it. We will keep this in mind in our proposal and pursue clear connections between intangible resources and activities and consequent wealth (see table 3 ). With regard to the frequency in the elaboration of the indicators, it will depend on factors like the type of organization, the dynamics of the industry or on strategy although we recommend a minimum of once a year.

Our proposal classifies SC into two basic blocks: Organizational Capital and Technological Capital indicators. The main reason is to take into account the important paper played by Technological Capital in innovation processes (CIC, 2003) and, besides, the different nature, strategic implications and management processes needed in both cases (Tseng \& Goo, 2005). 
Table 3: A System Of Indicators For SC: A Proposal

\begin{tabular}{|c|c|}
\hline \multicolumn{2}{|c|}{ STUCTURAL CAPITAL } \\
\hline \multicolumn{2}{|c|}{ ORGANIZATIONAL CAPITAL } \\
\hline Infrastructure & $\begin{array}{l}\text { Knowledge related to organizational mission } \\
\text { Knowledge related to business philosophy } \\
\text { Organizational structure } \\
\text { Social climate } \\
\text { Organizational development } \\
\text { Organizational stability } \\
\text { Social compromise with the environment }\end{array}$ \\
\hline $\begin{array}{l}\text { Quality evaluation } \\
\text { Processes }\end{array}$ & $\begin{array}{l}\text { Business management models } \\
\text { Shared strategic management } \\
\text { Strategic reflection processes } \\
\text { Organizational learning capacity }\end{array}$ \\
\hline TECHNOLOGIC & CAPITAL \\
\hline $\begin{array}{l}\text { Technological } \\
\text { effort }\end{array}$ & $\begin{array}{l}\text { Organizational innovation and development } \\
\text { Protected internal and external knowledge } \\
\text { Non-protected intellectual property }\end{array}$ \\
\hline
\end{tabular}

Organizational Capital is constituted by all the aspects related to the organization of the firm and the decision-making process (Ordoñez de Pablos, 2004). These assets are difficult to imitate, substitute and transfer and, in turn, this makes them a valuable source of sustainable competitive advantages. These assets are directly owned by the organization and, therefore, they are more easily managed in comparison to $\mathrm{HC}$ and $\mathrm{RC}$-owned by employees and customers, respectively-.

Within Organizational Capital two basic frameworks can be identified; one is based on infrastructure and the other on organizational processes. Organizational infrastructure is defined as the set of values and beliefs that are shared by employees and that contribute to the understanding of the functioning of the firm and of the value created through organizational structure. Organizational processes includes those resources and activities that make present functioning possible, such as internal processes or organizational learning and capacity to generate value in the future.

Technological Capital is integrated by intangible assets that are responsible for obtaining and developing products and services, as for example, the acquisition of necessary knowledge for product and service innovation. Below, we present and explain the different indicators for each type of Capital.

\section{ORGANIZATIONAL CAPITAL}

\section{Infrastructure Framework}

1. Degree of consciousness and internalization of organizational mission by employees.

2. Degree of knowledge regarding business philosophy, understood as a clear understanding of business management.

3. Existence of organizational infrastructure. Employees should clearly know and understand task distribution, their responsibilities and contribution to the decision making process, along with which are the formal relations between the different elements.

4. Social climate. The existence of a pleasant working atmosphere and active employee contribution to management improves level of satisfaction, both individually and collectively. 
To measure the four indicators described above, a seven scale (from 1 to 7 ) personal questionnaire for employees is proposed.

5. Organizational development. Organizational structure should allow for necessary adjustments to be made, given environmental changes. We suggest an indicator based on the perception that hierarchical superiors have about the capacity of development of the organization, valued on a scale from 1 to 7 .

6. Organizational stability. The age of the organization can be employed to measure stability and the level of knowledge accumulation or experience effect.

7. Social and environmental commitment. This can be valued through the economic quantity dedicated to environmental investment and cultural and solidarity projects.

\section{Process Framework}

1. Systems to evaluate process, product and service quality. The following indicators can be taken into account:

- $\quad$ Error percentages for different activities.

- $\quad$ Number of certifications the firm has received.

- $\quad$ Existence of teams of workers dedicated to internal progress and technological innovation.

- $\quad$ Percentage of employees that have information on total quality programs.

2. Existence of business management models. The number of management models specifically created for the organization and the level of investment in these can be used as indicators.

3. Shared strategic management. Indicators should include the number of employees that participate or have participated in the past in building shared strategic plans.

4. Shared strategic reflection. Organizations should periodically design, define and revive strategy and, therefore, the frequency of these activities is a useful indicator.

5. Learning capacity. Firms must create environments to favor learning, organizational guidelines, manners of capturing and transmitting knowledge and, moreover, situations to create and develop knowledge. The learning capacity of a give organization can be measured through the following indicators:

- $\quad$ Number of mechanisms to transmit and communicate knowledge.

- Degree of effective use those mechanisms. This indicator is calculated taking into account the results of a personal questionnaire where employees should value from 1 to 7 their degree of knowledge regarding the use and existence of the mechanisms described above.

\section{TECHNOLOGICAL CAPITAL}

It is integrated by technical skills that are developed by different groups given that they collaborate with each other. These skills are a source of technology in the sense that they are intangible resources directly responsible for the development of activities and functions to be performed by the technical operational system of the organization, both related to products or efficient production processes and future innovations.

1. Technological effort. Organizational effort in the acquisition of new technologies related to the productive and to information and communication systems. We propose the annual level of investment in technology as an indicator.

2. Organizational innovation and development. All organizations must evolve in order to adapt to changing customer requirements. Therefore, the following indicators are recommended:

a. Innovation investment, this is, the annual investment in the development of new products, process improvement, development of new markets or in R\&D projects.

b. The existence of working teams dedicated to improvement.

c. Number of new products, production processes and management methods over the last year. This indicator provides information on the results of innovation of the organization.

3. Knowledge regarding internal and legally protected items (patents, know-how, intellectual property, production or commercial secrets, exclusive design rights, licenses, concessions, inventions and formulas, etc.

4. Knowledge regarding external and legally protected items (trademarks, logotypes, copyrights, slogans, etc.) 
5. Knowledge related to non-protected intellectual property (know-how, know-why, know-what, etc.)

6. Existing data bases on information about the environment or customers. We consider that the annual investment in information systems as an adequate indicator.

\section{CONCLUSIONS}

IC management is a key organizational element for obtaining sustainable competitive advantages. Within IC, the importance of SC is outstanding, given that it constitutes the part of knowledge that the organization has internalized and, therefore, that belongs to the company (Camisón et al. 2000). It includes all organizational intangible resources that are not related to $\mathrm{HC}$, from culture to internal processes, information systems or data bases (Bontis et al. 2000).

In this paper we have examined the most relevant contributions that IC models have made with respect to $\mathrm{SC}$ and presented the most common indicators. Unlike $\mathrm{HC}$ and RC for which certain consensus exists, the literature review evidences that the study of SC is subject to relevant difficulties. Some authors have considered it an individual block with its own dimensions that include knowledge created, spread and used in the organization (Kaplan and Norton, 1992; Sveiby, 1997), while others have subdivided it into Organizational and Technological capitals in order to improve management. Moreover, some papers include RC within SC (Edvinsson, 1997). All in all, many different conceptualization frameworks can be identified and, definitely, this limits the possibility of using homogenous indicators for comparing organizations.

From a strategic perspective, SC improves knowledge transfer and organizational efficacy given that it adequately integrates all firm activities. $\mathrm{HC}$ and RC, quite on the contrary of SC, are not permanent and, therefore, an important objective within IC management is to convert them into SC (Martín and García, 2003). Organizations must be aware that $\mathrm{HC}$ is the base of knowledge creation which is then shared, used and spread through RC. Finally, this knowledge is institutionalized and incorporated to organizational SC.

It is in this context in which we have developed our system of indicators for SC management. The aim is to provide a clear vision of the bonds between organizational resources and strategic resources and the generation of wealth that they entail. The basic contribution of our work is the obtaining of indicators for SC management in order to help managers face up existing challengers. On one hand, we are aware that this may be overambitious but, on the other, we detect the need to provide organizations with a simple and common guide to manage SC within the IC framework.

\section{AUTHOR INFOMRATION}

Ma Teresa García-Alvarez, Rosa Mariz-Perez and Mercedes Teijeiro-Alvarez are assistant professors in business organization at the University of La Coruna in Spain. All three received her PHD in economics and business administration. Research interests of Teresa García-Alvarez are related to intangible resources and innovation. Rosa Mariz-Perez is specialized in intangibles and franchising and Mercedes Teijeiro-Alvarez is basically focused on themes related to human capital and intellectual capital.

\section{REFERENCES}

1. Alama, E.M. (2007): Capital intelectual y resultados empresariales en las empresas de servicios profesionales de España. Tesis Doctoral, Universidad Complutense de Madrid.

2. Barney, J. B. (1986): "Strategic factor markets: expectations, luck and business strategy", Management Science, vol. 32, pp. 1231-1241

3. Bontis, N. (1996); There is a price on your head: managing intellectual capital strategically, Business Quarterly, vol 60, n 4, pp. 40-47.

4. Bontis, N. (1998): "Intellectual capital: An exploratory study that develops measures and models, Management Decision, 36, pp. 63-76. 
5. Bontis, N., Chúa, W.C. and Richardson (2000): Intellectual capital and business performance in Malasya industries, Journal of Intellectual Capital, vol. 1, $\mathrm{n}^{\mathrm{o}}$ 1, pp 85-100.

6. Bradley, K. (1997): Intellectual Capital and the New Wealth of Nations II, Business Strategy Review, Vol. 8(4). Pp. 33-44.

7. Brooking, A. (1996): Intellectual capital. Core asset for the third millennium Enterprise, International Thomson Business Press, Londres, $1^{\text {a }}$ ed.

8. Bueno, E. (2005): Génesis, evolución y concepto del Capital Intelectual: Enfoques y modelos principales, Capital Intelectual, $\mathrm{n}^{\circ}$ 1, pp. 8-19.

9. Bueno, E., et al. (2003):"Hacia un modelo integrador de los procesos de negocio, conocimiento y aprendizaje en las organizaciones, Comunicación presentada en el XIII Congreso Nacional ACEDE: Dirección de empresas y creación de valor en un nuevo entorno económico, institucional y cultural, Salamanca, septiembre 2003.

10. Camisón, C.; Palacios, D. and Devece, C. (2000): Un nuevo modelo para la medición del Capital Intelectual en la empresa: El modelo Nova, $X$ Congreso Nacional ACEDE, Oviedo, septiembre.

11. Carson, E.; Ranzijn, R., Winefield, A. and Marsden, H. (2004): Intellectual Capital. Mapping Employee and Work Group Attributes, Journal of Intellectual Capital, $\mathrm{n}^{\circ}$ 5, pp. 443

12. CIC-IADE (2003): Modelo Intellectus: Medición y gestión del capital intelectual, Documento Intellectus $\mathrm{N}^{\circ}$ 5, Madrid.

13. Collis, D.J. and Montgomery, C.A. (1995): Competing on resources: strategy in the 1990s, Harvard Business Review, Julio-Agosto, pp. 118-128.

14. Covo, A. (2006); Modelos de Capital Intelectual de la Consejería de Educación de Junta de Andalucía. Indicadores de Capital Humano y Gestión del Conocimiento. Tesis doctoral. Universidad de Málaga.

15. Edvinsson, L. (1997); Developing Intellectual Capital al Skandia, Long Range Planning, nº 30, pp. 336373.

16. Edvinsson, L. and Malone, M.S. (1997): Intellectual capital. Realizing your company's true value by finding its hidden brainpower, Harper Collins Publishers, Inc., $1^{\text {a }}$ ed

17. Edvinsson, L. and Malone, M.S. (1999): El capital intelectual: cómo identificar y calcular el valor de los recursos intangibles de su empresa, Barcelona: Gestión 2000.

18. Euroforum (1998): Proyecto Intelect. Medición del Capital Intelectual, Madrid: Instituto Universitario Euroforum Escorial.

19. European Commission (2006): RICARDIS: Reporting Intellectual capital to augment research, development y innovation in SMEs, descargable en http://ec.europa.eu/invest-inresearch/pdf/download_en/2006-2977_web1.pdf.

20. Kaplan, R. and Norton, D. (1992): Balanced Scorecard-Measures that Drive Performance, Harvard Business Review, January-February, pp. 71-79.

21. Kogut, B. and Zander, U. (1996): What firms do? Coordination, identity and learning, Organization Science, 3 pp. 383-397.

22. Lev, B. (2001); Intangibles: management, measurement and reporting, The Brookings Institution. Washington, D.C.

23. Martín de Castro, G. and García Muiña, F.E. (2003): Hacia una Visión Integradora del Capital Intelectual de las Organizaciones, ICE, Boletín Económico, 2756, 7-16.

24. MERITUM (2000): Guidelines for the Measurement and Disclosure of Intangibles, First Draft. Paper presented Meritum meeting. Sevilla, 27-29 Enero

25. Nonaka, I. (1991): The knowledge-creating company, Harvard Business Review, November-December, pp. 96-104.

26. Ordoñez de Pablos, P. (2001): Relevant experiences on measuring and reporting intellectual capital in European pioneering firms, in Bontis, N. and Chong C. (Eds): World congress on intellectual capital readings, Ed. Butterworth-Heinemann.

27. Ordóñez de Pablos, P. (2004): El capital estructural organizativo como fuente de competitividad empresarial: un estudio de indicadores, Economía Industrial, no 357, pp. 131-140.

28. Porter, M.E. (1980): Competitive Strategy, Free Press, New York.

29. Roos, J., Roos, G., Dragonetti, N. and Edvinsson, L. (1998): Intellectual Capital: Navigating in the New Business Landscape, New York, New York University Press. 
30. Ross, G. and Ross, J. (1997): Valuing intellectual capital: The next generation, Financial Times, Mastering Management, mayo.

31. Snell, S.A.; Lepak, D.P. and Youndt, M.A. (1999): "Managing the architecture of intellectual capital: implications for strategic human resources management", en Ferris, G.R. (Ed.): Research in personnel and human resources management, S4, pp. 175-193.

32. Stewart, T.A. (1997): La nueva riqueza de las organizaciones: el Capital Intelectual, Ed. Granica, Barcelona.

33. Sveiby, K.E. (1997); The intangible assets monitor, Journal of Human Resource Costing and Accounting, vol 2, no 1, pp. 73-97.

34. Tejedor, B. and Aguirre, A. (1998): Proyecto logos: investigación relativa a la capacidad de aprender de las empresas españolas, Boletín de Estudios Económicos, vol. LIII, № 164, pp. 231-249.

35. Tseng, C. Y. and Goo, J. J. (2005), Intellectual capital and corporate value in an emerging economy: empirical study of Taiwanese manufacturers, $R \& D$ Management, 35(2), pp. 187-201.

36. Wernerfelt (1984): A resource management, manufacturing strategy and firm performance, Academy of Management Journal, vol 39 (4), pp. 836-866. 